\title{
Small and Medium Enterprises in Mexico and the Craft Beer Sector in Baja California: Dynamic Capabilities, Culture, and Innovation
}

\begin{abstract}
This article studies how Small and Medium Enterprises (SMEs) operating in emerging economies implement adaptative strategies to respond to constant changes in demand and global uncertainties, such as those stemming from the current SARS-COV2 pandemic. In this study the knowledge management capabilities used by SMEs in the craft beer sector in a region of northern Mexico are the focus of analysis. The objective is to present the competitive capabilities that craft beer sector has demonstrated in Baja California region and how small companies compete with the national industrial brewery and survive. Sources are data from a sample of companies and interviews with brewery owners, with which the analysis approaches, also, the Baja California business environment. The article highlights the routes of creativity, innovation, and symbolic capital of the companies in the region, and uses ideas from dynamic capabilities and knowledge management theoretical frameworks, to understand the craft brewery milieu. The conclusions in this article include the confirmation about the usefulness of these analytical frameworks based in the capabilities approach and the territorial knowledge. Also, the description of the existence of a complex Baja Californian milieu, where a multimodal scheme of craft beer characterized by different places of distribution and types of beer container, food-districts, at Mexicali, Tijuana, and Ensenada and a second generation of entrepreneur groups leading local business, is identified.
\end{abstract}

Keywords: Brewery Milieu; Dynamic Capabilities; Innovation; Culture and Creativity; Baja California.

Corresponding author: e-mail: almaraz@colef.mx

Received 21 September 2020 - Accepted 28 May 2021

This is an Open Access article distributed under the terms of the Creative Commons Attribution-Non-Commercial-No Derivatives License (http://creativecommons.org/licenses/by-nc-nd/4.0/), which permits non-comercial re-use and distribution, provided the original work is properly cited, and is not altered or transformed in any way. 


\section{Introduction}

The evolution of the global economy is forcing companies to adopt new strategies in the short and medium term. While the more vulnerable a national economy is, the firms must implement more aggressive actions to resist and survive. Given this situation, it is necessary to question if small and medium enterprises are a group that corresponds to the apparently least, resistant, excluded and most vulnerable sector in the innovation process. This article contributes to indicate the complexities involved in such an assumption, and how competitiveness can be represented with different models of entrepreneurship, with the case study approach of the craft brewery in Mexico and the analytical tool of theoretical frameworks from the dynamic knowledge management capabilities approach (Penrose [1959] 1995, Verona and Ravasi 2003, Adner 2003, Aguilera 2020).

The main research questions guiding this research have been: should the apparent fragility of SMEs be analyzed as a homogeneous situation in the emerging economies? Can the recent boom of SMEs in the craft beer industries in Mexico help understand new routes of competitiveness? The hypotheses are that the apparent universal fragility of SMEs is not that general neither homogeneous, because the competitive capacities depend on territorial aspects and temporal changing dynamics. Also, on the owners' management and knowledge capacities, which gives an increase to dynamic and geographical differentiable competitive capabilities. The statistics of the craft beer sector and the testimonies of owners in the northern border of Mexico refer to dynamic innovation processes. Some findings are to highlight: the territorial and cultural aspects associated with management and knowledge around the craft beer process; the symbolic business capital emboldened in the craft brands; the craft beer connection to the regional gastronomic sector; the owners' aspirations and intentions closely associated with 
creativity and innovations; multimodal and a model expressed in diverse individual and collective dynamics, including the participation of women brewers.

The first section will present a classification of Latin American SMEs, introducing heterogeneous innovation capabilities of small business owners who were interviewed between 2018-2019. The second is focused on the analysis of the entrepreneur's behavior and the current context of Mexican SMEs. The third section is dedicated to the boom of craft beer in Mexico started in 2013, the routes of creativity and innovation, and the symbolic capital business in the Baja Californian craft beer environment. The last section resumes the findings and remarks the opportunity to reconsider ideas about what we believe are often simplistic points of view on business organization limits and large corporations, through the example and lessons from the analysis of the craft beer industry in Baja California.

\section{Small and Medium Enterprises in Latin America}

It is interesting to highlight at least three aspects regarding the development of companies with less than 250 employees in emerging economies such as those that exist in Latin America. On the one hand, the challenges that SMEs face to stay in the market and survive. On the other hand, the SME classification and monitoring problem and the different parameters used among Latin American countries. And, lastly, the problems associated with the monitoring of informal businesses and businesses that are driven by individuals but are not registered as companies, which prevents accurate data on business competitiveness. Despite the fact that Mexican craft brewery is part of this scenario, the experience of entrepreneurs allows identifying adaptive organizational modes and competitive capacities. 
In Latin America, the type of risks experienced by Latin American SMEs in the startup phase is not precisely known. This situation is associated, in most countries, with a lack of records of these groups of businesses. This situation is contradictory in countries like Mexico where 97\% of businesses correspond to those with less than 250 employees. Despite this, there seems to be a consensus among various institutions that SMEs are vulnerable, and their lifespan is short. OIT (2009) reports that the survival rate of micro and SMEs is higher in Europe, between 75$77 \%$ in the two first years. While even though there is no consolidated information to Latin America, this institution refers to the survival rate of $45 \%$ in three years. Molina-Ycaza and Sánchez-Riofrío $(2016,27)$ consider the Economic Commission for Latin America and the Caribbean (ECLAC) reports about the disadvantageous conditions of micro and SMEs in Latin America and emphasize: "growth for this group of companies is a long road that not all go through since there are many that close shortly after opening".

Also, Lederman, Messina, Pienknagura and Rigolini, call attention to entrepreneurship in Latin America forewarning that:

Given a skill set wages are higher in the most productive companies, which are also often the largest, around the world. For example, in LAC, medium-size companies pay salaries that are 20-40 percent higher than those of small companies; likewise, large companies pay salaries that are 30-60 percent higher. (Lederman et al. 2014, 2)

For these authors, the entrepreneur makes the difference, in the "medium and large companies, which are generally run by the most dynamic entrepreneurs, are also the ones most likely to innovate in different ways" (Lederman et al. 2014, 2).

Therefore, if: "behind the most dynamic and productive companies - those that innovate, whose production is expanding and whose job creation rate is relatively high - there are creative entrepreneurs" (Lederman et al. 2014), it is important asking for the differences between 
competitiveness and entrepreneurship in the SMEs, but also between business, sectors, and regions. At the same time, this situation suggests going beyond the financial institutional instruments, as the main supports that SME requires. From our point of view, the Latin American SMEs, including Mexican ones, are in front a limited conception of how the entrepreneurship process occurs which excludes cultural and spatial features as part of its complexity. All SMEs go through the startup phase, but it is unknown how business ideas fail or progress, and what happens before reaching the market. This is the key feature to understand its survival because it is related to the knowledge managed by entrepreneurs.

The ECLAC emphasizes the dimension of policy instruments to improve SME development, such as financing and supporting for production chains and business networks to encourage entrepreneurship (Dini 2010). However, the first life cycle of companies moving forward before entering the market should not be obvious because it requires many steps to materialize entrepreneurship.

Lederman, Messina, Pienknagura and Rigolini consider "many possible reasons why Latin American and Caribbean companies grow as slowly as they do and [one of them is] the deficiency in the innovation" (Lederman et al. 2014, 8). For these authors "the companies need to innovate continually to grow (or even to survive)". Nevertheless, many companies are not interested in innovation, the owners do not know how to do it, or they fear doing it. In contrast, there are startups that emerge as innovators although their innovation capacities are weak, or the adopted strategies are simple, as the last section of this article show for the craft brewery. It is true that innovation is part of the dynamics of businesses to its endurance and particularly to entry into big markets and exporting. But what happens when a small business has been acquired by a large corporation? How the SMEs entrepreneurs acquire knowledge to innovate? 
How an entrepreneur selects ideas to startup an innovator small business specialized in craft beer? And how an entrepreneur uses its social and symbolic capital to configure entrepreneurial networks and innovate?

The discussion about the history of companies that arise and survive, especially SMEs, must focus on entrepreneurship as a multidimensional problem. Because "simple definitions do not refer to the heterogeneity of innovative actions that this phenomenon encompasses" (Lederman et al. 2014) New companies that do not innovate can be excluded from the entrepreneurship analysis, missing their experiences. For many Latin American countries, the SMEs relevance lies in generating employment, and not in the shift and share into innovation systems either. Also, SME reports have different scopes. In Argentine, a study carried out in 1996 by the FIEL, the total SMEs (less than 50 employees) represented for this year $99.2 \%$ of all units. This analysis found that SMEs have a low impact caused by government policies to improve their position and competitive conditions. One reason was that "beneficiaries of industrial promotion and the recipients of public credits corresponded to larger companies in the majority" (FIEL 1996, 308). In Mexico, SMEs have been followed recently by the government. Since 2015 a survey was elaborated to know about the competitiveness of small companies The results have been published twice and allow to know the weakness and vulnerability of business.

Based on recent fieldwork, innovation adopts different levels in SMEs. ${ }^{1}$ This situation can be related to the sector and founder's aspirations, the innovation of retail commerce activities being

\footnotetext{
${ }^{1}$ Between August 2018 and February 2019, semi-structured interviews to entrepreneurs were carried out. Ten companies with less than 10 employees were selected, including craft breweries in Baja California. With an intentional non-probabilistic sample, the objective was to obtain qualitative information on the enterprises in different cities of Latin America (Buenos Aires, Neuquén, Asunción, Tijuana, Ensenada). The questions were about the start of the ventures, innovation, business plan and financing.
} 
the less intensive. However, when trying to find a connection between innovation and productivity, or and innovation and profits, it was not possible to reach definitive conclusions, due to the intentionality and aspiration of the founders. The experiences of the founders interviewed in Tijuana (Mexico), Asunción (Paraguay), as well as in Buenos Aires and Neuquén (Argentina), reflected how business evolution with different ages was aligned with the instinct of entrepreneurs, while the path of innovation was mainly linked to the sectorial nature of activities. Based on these preliminary results studies with multiple analytical are required. On the one hand about the company in its industry and territory, and on the other hand about the aspirations and knowledge with which the entrepreneur starts a business (Table 1).

TABLE 1. Overview of ventures: SMEs from Argentina, Paraguay, and Mexico.

\begin{tabular}{|c|c|c|}
\hline $\begin{array}{c}\text { Company name / } \\
\text { location }\end{array}$ & Summary of startup & $\begin{array}{l}\text { Innovation capacities } \\
\text { and manage of } \\
\text { knowledge }\end{array}$ \\
\hline $\begin{array}{l}\text { Sabater Brothers / } \\
\text { Palermo, } \\
\text { Argentina }\end{array}$ & $\begin{array}{l}\text { Mr. Sebastián Sabater, a perfume specialist (graduate } \\
\text { in Italy), started selling handmade soaps at fairs with } \\
\text { his daughter Eliana after being fired. He started his } \\
\text { own business during the Argentine crisis between } \\
2001 \text { and } 2002 \text { (entrepreneur by necessity). The } \\
\text { initiative matured and led him and his family to found } \\
\text { "Sabater Hermanos". The product is made in the } \\
\text { family business. The creations are innovative in the } \\
\text { final product (varieties of aromas and size). In } 2018 \\
\text { the family already had four stores, three in Argentina } \\
\text { and one more in Barcelona, Spain. The four } \\
\text { commercial businesses have one or two workers, } \\
\text { being one of them the owner. }\end{array}$ & $\begin{array}{ll}\text { High } & \text { industrial } \\
\text { innovation } & \text { capacities } \\
\text { developed } & \text { by the } \\
\text { founder } & \end{array}$ \\
\hline $\begin{array}{l}\text { Catering service / } \\
\text { Asunción, } \\
\text { Paraguay }\end{array}$ & $\begin{array}{l}2016 \text { Ana Morinigo started in Asunción, Paraguay, } \\
\text { her own business without an established brand. The } \\
\text { catering services are focused on public offices. The } \\
\text { founder has no employees, and she has doubled her } \\
\text { sales in just one year (2018). She seeks to expand her } \\
\text { client portfolio without neglecting the competitive } \\
\text { advantages that she has: punctuality and direct contact } \\
\text { with the client. The entrepreneur is aware that her } \\
\text { advantages can also be limited to growth. She does not } \\
\text { think of herself as innovative. }\end{array}$ & $\begin{array}{l}\text { Medium distribution } \\
\text { and cook innovation } \\
\text { capacities developed } \\
\text { by the founder }\end{array}$ \\
\hline $\begin{array}{l}\text { Ecléctiko } \\
\text { (Furniture }\end{array}$ & $\begin{array}{l}\text { Two decorators and founders of this business are from } \\
\text { Tijuana, Mexico. They started up a business in } 2018\end{array}$ & $\begin{array}{l}\text { Low paint and } \\
\text { commercial }\end{array}$ \\
\hline
\end{tabular}




\begin{tabular}{|c|c|c|}
\hline $\begin{array}{c}\text { Company name / } \\
\text { location }\end{array}$ & Summary of startup & $\begin{array}{c}\text { Innovation capacities } \\
\text { and manage of } \\
\text { knowledge } \\
\end{array}$ \\
\hline $\begin{array}{l}\text { intervened with } \\
\text { Art) / } \\
\text { Tijuana, Mexico }\end{array}$ & $\begin{array}{l}\text { out of an innovation plan. This business renews used } \\
\text { furniture intervening in an artistic way. When the } \\
\text { intervention finished the furniture starts the second } \\
\text { cycle of life and can be sold. Since the beginning, the } \\
\text { store was formally established but not as a } \\
\text { commercial firm. In } 2019 \text { the founders dissolved their } \\
\text { informal society, but the original idea has been } \\
\text { continued by one of them. For two years the business } \\
\text { has maintained the same level of sales and growth } \\
\text { medium-low level. In the summer of 2020, the } \\
\text { founder has received a proposition to expand her } \\
\text { business with a second store. }\end{array}$ & $\begin{array}{l}\text { innovation capabilities } \\
\text { developed by the } \\
\text { founder }\end{array}$ \\
\hline $\begin{array}{l}\text { Handicrafts from } \\
\text { Argentina } \\
\text { Neuquén, } \\
\text { Argentina }\end{array}$ & $\begin{array}{l}\text { The sale of handicrafts of Argentine and Uruguayan } \\
\text { origin in the city of Neuquén, in southern Argentina, } \\
\text { is a business that is sought like a needle in a haystack } \\
\text { because this place is not a tourist destination. The } \\
\text { entrepreneur of one of these businesses, located in a } \\
\text { little mall, decided to start up the store responding to } \\
\text { the increasing arrival of foreign workers who } \\
\text { demanded local products from the region such as } \\
\text { mate, jams, and honey. The owner supplies herself } \\
\text { with typical products from Argentina and Uruguay, } \\
\text { but without a specific business strategy and no plan } \\
\text { for to medium and long term. The competitive } \\
\text { advantages of the business are the location, few } \\
\text { competitors in Neuquén, and a variety of products } \\
\text { offered. }\end{array}$ & $\begin{array}{l}\text { Low commercial } \\
\text { innovation capabilities } \\
\text { developed by the } \\
\text { founder }\end{array}$ \\
\hline $\begin{array}{l}\text { Verdulería Valerio } \\
\text { Buenos Aires, } \\
\text { Argentina }\end{array}$ & $\begin{array}{l}\text { The dynamics of the Buenos Aires greengrocers } \\
\text { attended mostly by Bolivians depends in the first } \\
\text { place on a strategic location. They function as } \\
\text { convenience stores located every two hundred meters } \\
\text { on average. They are small stores operating in spaces } \\
\text { that are regularly } 20 \text { square meters, and not all of them } \\
\text { are recently created. They have a minimal } \\
\text { organization in the sale points, they seem improvised } \\
\text { and some look visually saturated; Businesses do not } \\
\text { innovate in commercial strategies to sell, although } \\
\text { depending on the neighborhood the stores offer } \\
\text { specific goods. Verdulería Valerio located at } 2601 \\
\text { Paraguay street offers fruits, vegetables, and products } \\
\text { for the Jewish population. The competitive advantage } \\
\text { is the quality and variety of fresh products. Families } \\
\text { that are operating the stores not always are the owners. }\end{array}$ & $\begin{array}{l}\text { Few business } \\
\text { innovation capabilities } \\
\text { developed by dealers } \\
\text { and/or founders. } \\
\text { Stores compete on } \\
\text { quality, freshness, and } \\
\text { variety of products. } \\
\text { Prices are not usually } \\
\text { lower than those of } \\
\text { large commercial } \\
\text { chains such as Coto, } \\
\text { Carrefour, or others. }\end{array}$ \\
\hline $\begin{array}{l}\text { Craft beer taste } \\
\text { rooms } \\
\text { Tijuana, Mexico }\end{array}$ & $\begin{array}{l}\text { The concept of "hall beer tasting" in Tijuana has been } \\
\text { successfully implemented in recent years. } \\
\text { Entrepreneurs in craft beer production have } \\
\text { experimented with different ways of entering local }\end{array}$ & $\begin{array}{l}\text { Competitive capacity } \\
\text { is associated with } \\
\text { prestige, which is } \\
\text { granted by consumers. }\end{array}$ \\
\hline
\end{tabular}




\begin{tabular}{|l|l|l|}
\hline $\begin{array}{c}\text { Company name / } \\
\text { location }\end{array}$ & \multicolumn{1}{|c|}{ Summary of startup } & $\begin{array}{l}\text { Innovation capacities } \\
\text { and manage of } \\
\text { knowledge }\end{array}$ \\
\hline & $\begin{array}{l}\text { markets. There are producers who sell beer in their } \\
\text { own homes; others now manage their testing rooms. } \\
\text { In these places, the owners can combine the sale of } \\
\text { beer without a bottle with the food offer, in others they } \\
\text { only offer beer. The installed production capacity is } \\
\text { directly proportional to the number of liters per week. } \\
\text { The brand and the product are associated with } \\
\text { prestige. The successful path is for those who have } \\
\text { managed, who have bottled their products, and who types of } \\
\text { beer, but the } \\
\text { prestigious beer } \\
\text { transferred this } \\
\text { attribute to the brand } \\
\text { as a explored other points of sale in the city or region, for } \\
\text { maintaining the indicators to be considered beer craft } \\
\text { example, "Lágrimas } \\
\text { Negras" from the } \\
\text { producers. }\end{array}$ \\
& $\begin{array}{l}\text { Ramuri brand. The } \\
\text { variety of products is } \\
\text { also a factor of } \\
\text { competitiveness, being } \\
\text { the knowledge of the } \\
\text { master in craft beer is } \\
\text { the main innovation } \\
\text { factor. }\end{array}$ \\
\hline
\end{tabular}

Source: Author's elaboration based on fieldwork (2018-2019).

Some business omitted a schedule and selection of ideas and designed an action starting plan with prototypes before entering the market, except the soap and beer entrepreneurs who did partially. In most cases, the local and regional market conditions, imposed adjustments to push the owners' startups to change the original ideas. The innovation only was considered by owners dedicated to soap and beer elaboration. The craft brewery caught the eye to focus deeper than the other activities. It is interesting because all craft beer companies in Mexico should stay small. $^{2}$ In Baja California the brewer's milieu is distinguished by local and regional networks that encourage incentives to owners to collaborate. The craft beer networks in Baja California are consistent with Dini (2010) studies about business networks:

\footnotetext{
${ }^{2}$ Mexican breweries have followed two references to be considered artisanal: Annual production (less than 50 hectoliters per moth), and the production process.
} 
[The networks] represent the most emblematic places where the operation can be seen and its potentialities, [... the] high social capital allows a significant decrease in transaction costs [... and] small companies can strengthen collaborative ties and achieve new competitive advantages through networks organization. (Dini, 2010, 21)

However, the territorial organization of companies is not registered by public institutions. Another problem is the monitoring of SMEs and the classification in LATAM.

The classification of SMEs in Latin America is a problem due to the different parameters to register companies with less than 250 employees. According to Molina-Ycaza and SánchezRiofrío (2016, 24), Argentina (which also divides medium-sized companies into two groups), Panama, and Peru, consider the sales volume to determine if a company is in the SME group; Colombia considers employees and the value of assets; Belize, Brazil, Chile, Ecuador, El Salvador, Paraguay, Puerto Rico, and Venezuela, consider employees and volume of sales; Bolivia, Guatemala, Honduras, and Mexico only employees; while Costa Rica, Nicaragua, Dominican Republic, and Uruguay, consider employees, the value of assets and volume of sales. This divergence makes the comparative monitoring of SMEs in Latin America very difficult. Also, some countries divide SMEs by sector. Table 2 shows the criteria for Mexico.

TABLE 2. Size of companies in Mexico by sector and employees

\begin{tabular}{|l|c|c|c|}
\hline Size & Manufacture & Commerce & Services \\
\hline Micro & $0-10$ & $0-10$ & $0-10$ \\
\hline Small & $11-50$ & $11-30$ & $11-50$ \\
\hline Medium & $51-250$ & $31-100$ & $51-100$ \\
\hline Big & $\geq 251$ & $\geq 101$ & $\geq 101$ \\
\hline
\end{tabular}

Source: INEGI, 2009.

By taking the employment and the concentration of business per location as main variables, Latin American countries can be compared, to measure innovation ecosystems, as well as business capacities, where knowledge management and cultural values are often relevant. Although it has been recognized that Brazil, Chile, Mexico and Colombia "show mature 
programs to support entrepreneurs [such as] the government agencies Corporación de Fomento de la Producción (CORFO) of Chile and the National Company for Financing Studies and Projects (FINEP) of Brazil [for its] standards of evolution in the design and development of programs adapted to the changes of the entrepreneurial actors in their respective countries" (SELA, 2016), there is a gap in the entrepreneurship promotion policies.

2.1. Mexican entrepreneurs in Small and Medium Enterprises from a new theoretical perspective

This article uses a theoretical framework that considers the entrepreneurial cultural and sociospatial aspects, by using two approaches: a) the dynamic capabilities and b) the entrepreneurs' knowledge management potential (Table 3). In both, the territorial context is a key component to understanding the spirit and aspirations of entrepreneurs. At the same time, the integral lens to analyze the startup phase according to Almaraz (2020) is adopted.

To Penrose ([1959] 1995), knowledge plays a crucial role in creating value for companies and has a major influence on their survival. Also, the author describes two kinds of knowledge relevant to a company's success: entrepreneurial knowledge and managerial knowledge. She considers that entrepreneurial knowledge relates to an entrepreneur recognizing and developing a business opportunity. But Penrose also distinguished two kinds of entrepreneurs that help to understand the complexity in the business decisions and the SMEs owners behavior, which should be present for studying emerging fields like the craft beer and their entrepreneurs:

There are some entrepreneurs who seem to be primarily interested in the profitability and growth of their firm as an organization for the production and distribution of goods and services. These we might call 'product-minded' or 'workmanship-minded' entrepreneurs or 'goodwill builders'. Their interests are directed towards the improvement of the quality of products, the reduction of costs, the development of better technology, the extension 
of markets through better service to consumers... Another type of entrepreneur, whom we might call the 'empire builder' is of a different order. He is pushed by visions of creating a powerful industrial 'empire' extending over a wide area. (Penrose, [1959] 1995, 39).

Later, Penrose's ideas were recovered by other authors that argue about the dynamic capabilities of entrepreneurs, overlapping aspects of business and management knowledge (Teece, Pisano and Shuen 1997, Zollo and Winter 2001). Adner and Helfat (2003) also mention that "managers may differ in their dynamic capabilities and therefore may make different decisions [and ...] because managerial decisions operate on the resource and capability base of an organization, differences between firms in their resources and capabilities may lead to differences in managerial decisions."

TABLE 3. Analytical approaches and components to study SMEs dynamic capabilities and knowledge management

\begin{tabular}{|c|c|}
\hline Dynamic capabilities and knowledge management & Components \\
\hline $\begin{array}{l}\text { Penrose ([1959] 1995, 9) } \\
\text { - "The patterns of economic life, are largely shaped by the } \\
\text { multitude, of individual decisions made by the } \\
\text { businessmen who guide the actions of the business units } \\
\text { we call firms." } \\
\text { - - "The business firm ... is both and administrative } \\
\text { organization and a collection of productive resources }[. . .] \\
\text { Enterprise, or entrepreneurship as it is sometimes called, } \\
\text { is a slippery concept, not easy to work into formal } \\
\text { economic analysis, because it is so closely associated with } \\
\text { the temperament of personal qualities of individuals." }\end{array}$ & $\begin{array}{l}\text { Knowledge } \\
\text { Management } \\
\text { Individual decisions } \\
\text { Enterprises }\end{array}$ \\
\hline $\begin{array}{l}\text { Teece, Pisano and Shuen (1997, 510-516) } \\
\text { - "Dynamic capabilities are the subset of } \\
\text { competence/capabilities which allow the firm to create } \\
\text { new products and processes and respond to changing } \\
\text { market circumstances" } \\
\text { "Dynamic capabilities,' as capabilities that enable an } \\
\text { organization 'to integrate, build, and reconfigure } \\
\text { competences'; "are the capabilities with which managers } \\
\text { build, integrate, and reconfigure organizational resources } \\
\text { and competences." }\end{array}$ & $\begin{array}{l}\text { Firms } \\
\text { New products } \\
\text { Market } \\
\text { Competences } \\
\text { Managers } \\
\text { Resources }\end{array}$ \\
\hline $\begin{array}{l}\text { Zollo and Winter (2001) } \\
\text { "Dynamic capabilities to date have focused on } \\
\text { organizational factors that enable firms to adapt to change" }\end{array}$ & $\begin{array}{l}\text { Organizational factors } \\
\text { Changes } \\
\text { Entrepreneurs }\end{array}$ \\
\hline
\end{tabular}




\begin{tabular}{|c|c|}
\hline Dynamic capabilities and knowledge management & Components \\
\hline $\begin{array}{l}\text { Adner and Helfat (2003) } \\
\text { "Dynamic managerial capabilities are the capabilities with } \\
\text { which managers build, integrate, and reconfigure } \\
\text { organizational resources and competences" }\end{array}$ & $\begin{array}{l}\text { Managers } \\
\text { Capabilities (to build and } \\
\text { integrate organizational } \\
\text { resources) } \\
\text { Competences }\end{array}$ \\
\hline
\end{tabular}

Source: Own, based on authors cited in the table.

In addition, SMEs entrepreneurs' decisions are part of knowledge acting as the first step of the venture associated to select ideas. But what is it that motivates decision-making beyond the intention of making a profit? In Almaraz (2020), a debate on startups and entrepreneurial behavior, proposing social and cultural aspects has been opened. The conception and selection of ideas, the prototype or startup phase, and the entry to the market, are three phases that involve internal and external dimensions related to entrepreneurship. The socio-cultural aspects as an external dimension are considered at the same level as institutional and technical-technological aspects. This external dimension opened again the discussion to analyze the entrepreneurial behavior interconnected to social and cultural values, codes, and meanings integrated in business capabilities. This makes possible a historical building process that should be named 'historical business social and symbolic capital'. Nevertheless, the landscape of SMEs in Mexico offered by the reports of the Ministry of Economy (2015 and 2019) based on the National Survey of Productivity and Competitiveness of SMEs (ENAPROCE) is far away from showing the dynamic capacities, knowledge management, and sociocultural components. Despite this, the following section offers an overview of the situation of Mexican SMEs and their entrepreneurial agents to contextualize in a broad sense the response possibilities of SMEs owners. 


\section{Overview of Small and Medium Enterprises in Mexico}

In Mexico and Latin America, the SMEs are overwhelmingly dominating both business and employment. ${ }^{3}$ Different discussions about this sector come from economists, sociologists, anthropologists, management studies. In Mexico the traditional views have focused on the impact of SMEs on GDP, the percentage of jobs and businesses in the national productive context, and also on their weakness; it last point has been explained by the scarcity of government political actions to strengthen their competitive capacity. Nevertheless, Dussel (2004), has pointed to academic and institutional studies on instruments and mechanisms to promote SMEs at the federal level in Mexico revealing the supply of government support services to SMEs in the last two decades. Despite this, Dussel (2004) points out some relevant aspects: SMEs have not stopped losing companies since the mid 1990s in Mexico, the disconnection of SMEs with the national productive core since the end of the 1980s and that SME's exports are low versus the increasing dependency on imports in their processes and sales. This scenario is explained by the high percentage of SMEs with fewer than 10 employees in the commercial sector and the low participation of SMEs in manufacturing activities. De Maria (2002) considers that structural changes in Mexico since the second half of the 20th century affected the development of SMEs. The financial support dedicated to promoting technological development in a context of low national competitiveness in 1970s did not have

\footnotetext{
${ }^{3}$ Between 2015 and 2016, the first business survey focused on micro, small and medium-sized companies was conducted by the now defunct Instituto Nacional del Emprendedor (INADEM). In others, like Argentina, there have been efforts for several decades, but they are not regular. Through the Fundación de Investigaciones Económicas Latinoamericanas (FIEL) -Latin American Economic Research Foundation-, the Argentine government obtained support to carry out a study ten years earlier (1995), on SMEs from a comparative perspective. The interest responded "on the one hand, to the importance observed of this type of companies in other experiences [considering that]" in industrial countries and in some developing countries with good performance, a high proportion of economic structures was [observed] of SMEs.
} 
the expected effects on SMEs. In the following decade (1980), Mexico promoted industrial reconversion to impulse technological development, but from a new model based on commercial openness and export orientation that most SMEs could not follow. The 1990s was reflected in the macroeconomic policy and the outsourcing was not favorable for all SMEs. The northern region distinguished itself as the best-positioned Mexican territory in the international outsourcing process (Dominguez and Brown 1989), concentrating companies linked to global production chains like low-cost labor units.

Recently the debate has moved beyond the weakness and mortality of SMEs to approaches on female participation from institutional, gender, and cultural studies (Inmujeres 2009, Banco Mundial 2010, Heller 2010, Hernández 2015, OIT 2015). When writing about entrepreneurial culture, many specialists think in sectoral groupings that have not been able to develop, instead of reflecting on chains and productive identity, and regional codes. Entrepreneurship and innovation have been enhanced as elements in recent debate for SMEs in Mexico (Angelelli and Llisterri 2003, Almaraz 2020).

According to ENAPROCE, in 2019 there were more than 4 million businesses with less than ten employees in this country, which barely managed to subsist with net earnings of $\$ 77$ per week. The most recent results of this survey, published in 2019, reported 4,180,986 business and almost 20 million employees in Mexico. Large companies accounted for $0.20 \%$ business and accounted $36 \%$ of employees, while small and medium-sized enterprises accounted $2.6 \%$ business and $16 \%$ of employees. While micro-businesses concentrated $97.2 \%$ and almost 50\%, respectively (Table 4). 
TABLE 4. Mexican SMEs: Economic Units by size, 2018.

\begin{tabular}{|l|c|c|c|c|c|}
\hline Size & $\begin{array}{c}\text { Economic } \\
\text { Units }\end{array}$ & $\begin{array}{c}\text { Total } \\
\text { Employment }\end{array}$ & $\begin{array}{c}\text { Employees by } \\
\text { unit }\end{array}$ & $\begin{array}{c}\text { \% Economic } \\
\text { Units }\end{array}$ & $\begin{array}{c}\text { \% } \\
\text { Employees }\end{array}$ \\
\hline Micro & $4,057,719$ & $9,505,392$ & 2.34 & 97.20 & 47.60 \\
\hline Small & 111,958 & $3,223,928$ & 28.79 & 2.60 & 16.14 \\
\hline Medium & 11,309 & $7,234,072$ & 639.67 & 0.20 & 36.20 \\
\hline Total & $4,180,986$ & $19,963,392$ & 4.77 & 100.00 & 100.00 \\
\hline
\end{tabular}

Source: Based on ENAPROCE (INEGI, 2018).

Manufacturing businesses with less than 250 employees concentrated $13 \%$ of total, services $36 \%$, and commercial $51 \%$ (INEGI 2018). In employment $21 \%$ was in manufacturing, $41 \%$ in commercial, and $38 \%$ in services. These percentages indicated that in 2018 at least 2 million Mexican SME businesses were in commerce employing at least 5 million workers; the service businesses exceed 1.5 million and concentrated almost 5 million employees; while the manufactures units, which barely exceeded half a million, employed 2.6 million. These data reveal, on the one hand, the weight of services and trade, compared to manufacturing in both indicators, but only in absolute terms, since the importance of manufacturing is concentrated in the ability to create a greater number of jobs per unit. Data for business with less than 10 employees in the 2018 survey, $48 \%$ corresponded to man owners, and 52\% to woman. Nevertheless, the national survey does not allow to obtain the balance by sector and owners by sex, or competitiveness indicators by subsector and owners' type.

3.1. Competitiveness, Managerial Aspects, and Training in Mexican Small and Medium Enterprises

The competitiveness of Mexican SMEs depends on their management capacity. ENAPROCE 2015 shows a worrying outlook. Almost half of SMEs with 0-10 employees, (47.6\%) did not have a plan to resolve operational and organizational obstacles. In the group of companies with 11-50 employees, $16.5 \%$ did not carry out an immediate action plan. In the 51-250 employees' 
group, only $8.4 \%$ did not have a plan. However, the data cannot be viewed by sector or region, or locality which prevents more complex analyzes about the behavior of entrepreneurs and sectors. The 2019 results changed the aggregation. Official data refer separately only to companies with 0-10 employees. In this case, the percentage with a problem-solving plan decreased to $40.4 \%$, but this means that 4 out of 10 micro businesses do not have an action plan to solve internal problems. Without an improvement plan, it is inexplicable how the owners manage growth and innovation.

Despite the limitations in monitoring the competitiveness of companies, a common denominator is that for both benchmark years (2014 and 2017), 66\% of companies with fewer than 10 employees do not monitor their performance. While in the rest of the companies the monitoring is presented in a range of $60 \%$ to $65 \%$ of the units. In this case, the mixture by sector is very important, since it is inferred that it is in the case of manufacturing where there is greater control, followed by monitoring in services and finally in the case of shops. Based on these inferences, the first hypothesis is that size is not the central factor of business vulnerability but rather the lack of an organizational structure and the type of sector and chain to which it belongs. By not requiring quality control in the production of merchandise, businesses are more likely to skip this step. Likewise, a business can subsist without a place for which rent is paid, or without occupied personnel since the owners, including the family, can take charge of the sales processes. What does not happen in an industrial workshop and in some services.

The management of knowledge is key to the innovation process. In 2015, ENAPROCE reported that only $12.6 \%$ SMEs provided training, included to the owners in business with $0-10$ employees. The $55.8 \%$ of small business (11 to 50 employees) provided training. And medium business (51 to 250 employees) $73.7 \%$ did so. The reasons to offer training vary in each case, 
but the limitation surveys do not allow elaborating final conclusions. ${ }^{4}$ Again, a crosstab at least by sector and size is needed. About the use of TIC, the 2019 ENAPROCE results show $72 \%$ of SMEs made regular use of a computer (2018), but a low proportion used it and Internet connection to increase the productivity or aspects related to the organization.

Financing, as an structural aspect, represents to Mexican SMEs a complicated scenario. In 2017, 7 of 10 business owners said that they do not trust to apply for a bank loan because the money was expensive. In businesses with 11 to 50 , and 51 to 250 the use of credit cards was $100 \%$, while only $1 \%$ in the smallest businesses (0-10 employees). It was explained by the necessity of daily cash. The $81.3 \%$ of SMEs requires cash to purchase daily inputs; purchase machinery $27.5 \%$, to do payments of credits $25.6 \%$, and to increase the production by only $11 \%$. The owner's reasons to not go to financial institutions are: they do not know the banking services (52\%), SME owners do not trust in their self-credit history and fear being rejected (16\%), and some owners do not need loans. In consequence, the SMEs limit their growth, they have low productivity and innovation, and little saving capacity. The ENAPROCE reported in 2015 that $14.7 \%$ of SMEs (three sectors $0-10,11-50$, and 51-250 employees) were not interested in growing. In the 2019 report, the percentage increased to $22.5 \%$. This proportion and tendency open new questions about the dynamics capabilities and knowledge management in SMEs, pushing to achieve studies by sector. The social structure by business and sector is not data available for the SMEs in Mexico.

\footnotetext{
${ }^{4}$ Among the reasons that stand out for not providing training are a) the cost of offering it and b) the idea or impression that it is not required because the knowledge of the workers and / or owners is adequate.
} 
The general analysis of the SME sector in Mexico shows its remarkable diversity, the financing as secondary goal owners', internal and external growth obstacles associated with government models in Mexico (before 1980 high protectionism and after the trade liberalization oriented to foreign markets), low management capacity, low educational capacity in most of the owners of SMEs, and startup associated to unemployed people. ${ }^{5}$

Entrepreneurship in Mexican SMEs is still very limited and highly segmented. Many examples may contradict general perspectives. The craft beer industry is distinguished by the creativity and innovation capabilities of owners. About the value chains and Mexican SMEs, the official data is not consistent, then coordination and productive networks cannot be analyzed at this moment in general terms. In this way, it is mandatory to generate information about the territorial innovation ecosystems linkages and evolution. This work could offer the pulse of productive and organizational chains of supply and value, not only for SMEs. Today, a large proportion of SMEs use direct profits to buy materials, but it is unknown in which value chains their exchange is concentrated.

Finally, the scenario for Mexican SMEs owners in general, is very complicated. The average profits obtained per week by SME, in 2018 , were 1,700 pesos, equally to 77 dollars per week (22 pesos/dollar), or 11 dollars a day. Despite the situation, there are industries such as the craft brewery that must remain small, where the nature of the activity requires constant innovation and the creativity to new final products. In Mexico, today is craft beer is being considered a

\footnotetext{
${ }^{5}$ Librado and Ramírez (2020), consider that entrepreneurship by necessity may be more explicit in commerce activities. While entrepreneurship by opportunity can be related to the proximity of markets. The $76 \%$ of SMEs in Mexico with less than 10 employees were in 2018 near their markets, so the idea of convenience proximity can illustrate the 'opportunity entrepreneurship', which does not solve the vulnerability in long run.
} 
sector of increasing profitability, where owners need minimal managerial capabilities because of the size of firms less than seven employees by business (Mexican Beer Association 2018), but a high knowledge in cooking and learning process capabilities to be creative. The owners need to be innovators and respond with quality products to access local markets of craft beer.

\section{The Boom of the Craft Brewery and the Dynamic Capabilities}

The word beer comes from Celtic Latin cerevisiae and corresponds to a non-distilled alcoholic beverage made from the cooking of barley grains. According to a recent report published by Deloitte $(2017,3)$, beer consumption continues to rise and currently represents $75 \%$ of the alcoholic beverages consumed in the world; the main markets are India, China, the United States, Brazil, Russia, Germany and Mexico. The beer introduction to Mexico occurred during the arrival of the Spanish in the 16th century. This drink gained surface thanks to the production of "pulque", which was a regional drink extracted from the maguey plant that is fermented in small barrels. The positioning of industrial beer in Mexico in the 19th Century resulted in a small group of long-lived companies located in the central area, Yucatán, and north of Mexico. Recio $(2004,7)$ refers to eleven beer brands constituted between 1896 and 1900, distributed in Chihuahua (1), Mexico City (3), Jalisco (1) State of Mexico (1), Nuevo León (1), Sinaloa (1), Sonora (1), Veracruz (1) and Yucatán (1).

According to INEGI $(2020,6)$, last year Mexican beer production was the most important in the alcoholic beverages branch which represents the highest percentages of jobs $(49.3 \%)$ and gross production $(65.0 \%)$. Table 5 are showed the features of the Mexican beer national industry. The Grand View Research (2020) and India \& US-based market research and consulting company, "the global number of craft brewers is increasing rapidly on account of 
the growing demand for the product". While the "Latest Research: Global Beer Industry (20172022)" has valued the global market at $\$ 530$ billion in 2016 , with a growth expectation in five years in $40 \% .{ }^{6}$ In the craft beer industry, production per brewery must be less than $6-7$ million barrels per year, not belong to a transnational company and have the recognition of a beer producer (Brewers Association, 2020). Most of the reports in the world refer to the beginning of craft breweries between 1970 and 1980, but in Mexico, it was until the mid-1990s. ${ }^{7}$ Although the boom of a craft brewery in Mexico become in the last ten years. In 2013 there were 300 microbreweries (Bernáldez 2013), in 2016 the businesses registered reached 560, mainly distributed in Mexico City (16\%), state of Baja California (13\%), and Jalisco (11\%). In 2018 the Mexican Beer Association reported 940 breweries.

In Mexico craft breweries are small businesses that do not produce more than 50 hectoliters per month. A craft beer has the following characteristics: It does not contain artificial elements, neither in the process nor in the ingredients, the fermentation is a natural process, and the flavors are the result of the mixture of water, malt, hops, yeast, and other ingredients like oatmeal. Also, it can contain fruits, spices, and herbs, chocolate, chili, and other ingredients depending on the

\footnotetext{
${ }^{6}$ To Grand View Research "the global craft beer market size was valued at USD 85.02 billion in 2015 and is expected to witness significant growth over the forecast period owing to the increasing penetration product in countries like South Africa, Australia, New Zealand, and Brazil.” (Grand View Research (2020).

${ }^{7}$ According to Guillén, Rendón and Morales (2016) the pioneering craft beer brands in Mexico: Cosaco from Mexico City, Calavera and Minerva from Guadalajara. Although the 1990s are referred to as the period in which the craft beer boom began in Mexico, the year 2000 is the watershed with the emergence of the Cosaco brand and the emergence of the first microbrewery in Mexico. These authors point out that in "2008, Bjorn Gilbert Nielsen created" Calavera in Mexico, after being awarded in Denmark. Its craft beers are distinguished by their proximity to Mexican cuisine from chocolate, coffee and morita, guajillo, ancho, and chipotle chilies (Guillén, Rendón and Morales 2016, 443).
} 
brewmaster's technique. It is an industry highly innovative because of combinations of flavors.

It is independent since by not belonging to the large corporations.

TABLE 5. Beer market and production of beer in Mexico according to INEGI (2020)

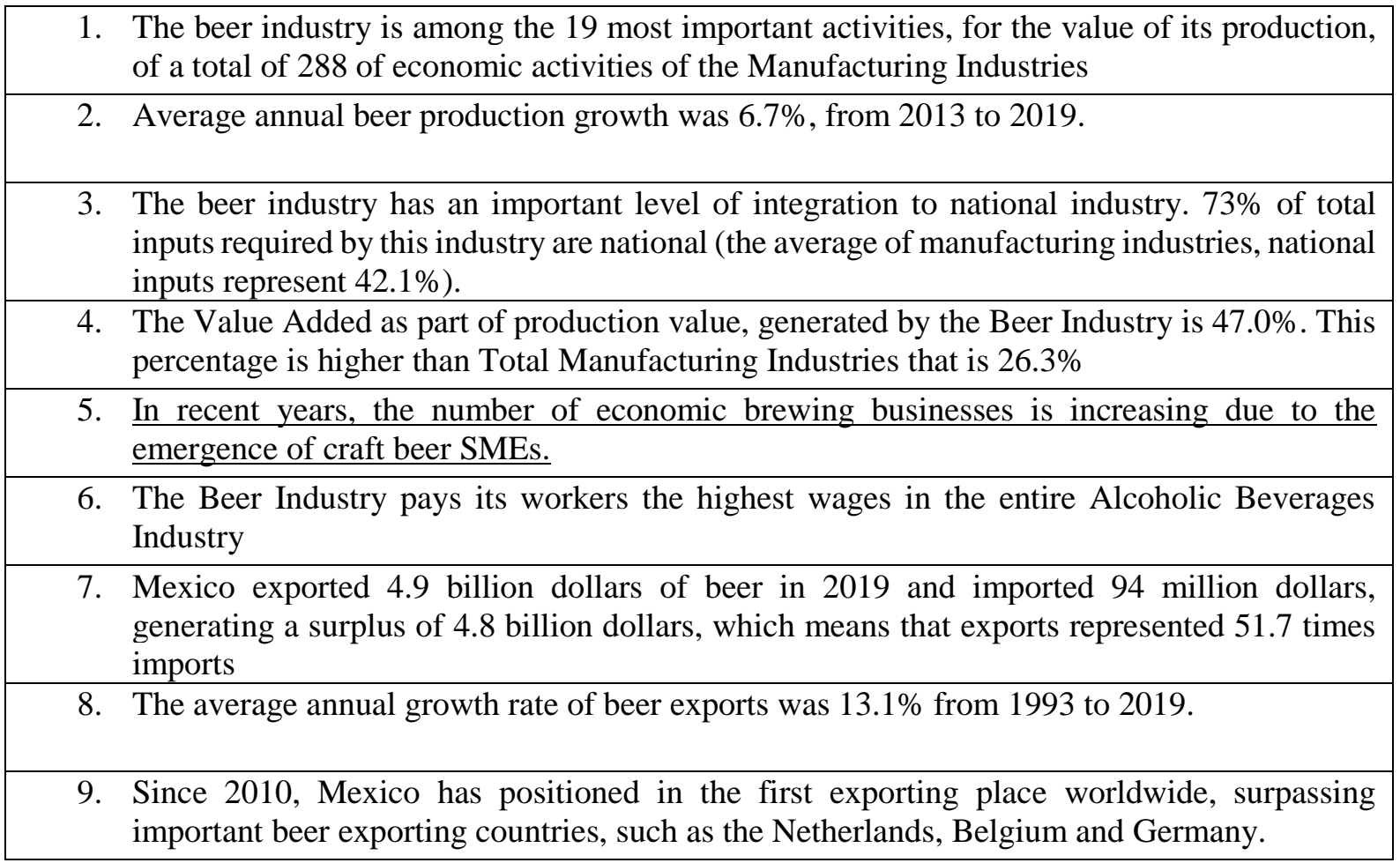

Source: Based on INEGI 2021.

\subsection{Knowledge, Collaboration, Creativity, and Cultural Dimension}

The recent literature published between 2017 and 2020 on craft beer has focused on three main aspects: knowledge, collaboration and creativity, and cultural dimension (symbolic capital) associated with geographical aspects. Each one refers to resources and consequently to dynamic capabilities experienced by brewers in multiple ways. A study case of craft beer focused on transfer of knowledge (TK) detected that it: "also plays a crucial role in the transition from the start-up phase to the development phase because [information] managing and growing a business is subtly different from the business skills necessary to start a business". [The capabilities of the owner are based on] "general knowledge about business planning; product 
knowledge regarding different kinds of beer and production technologies; and market knowledge" (Cardoni et al. 2018).

On the Northern border of Mexico, the owners of craft breweries, having fewer than 10 employees, even less than 5, for this reason, they don't have to transfer knowledge within the firm. They know the market and manage symbolic capital, in addition to having the basic brewing knowledge. Their local collaboration is very important to transfer knowledge between brewers. Collaboration and creativity a distinctive of the craft beer industry. To Cunningham and Barclay "a key theme to emerge from this artistic and intrinsically creative sector is the dependence on collaboration between entrepreneurial agents" (Cunningham and Barclay 2020, 263). To these authors, focused on the Northeast of Scotland, the growth of craft beer come from a deep-rooted collaboration, as well as a reaction to and in resistance of large companies' competition. This is relevant because the craft beer sector on the northern border of Mexico exists a high level of collaboration and it is geographically the main characteristic. Cunningham and Barclay (2020, 263-264) assume that collaboration in the Northeast Scotland craft beer sector has geographical connections between consumers, suppliers, and another brewer. Consequently, "the idea of place posits an informing element to how collaboration is developed, not necessarily creating boundaries in scope but certainly leading to a prioritization of who is important in terms of stakeholders" (Cunningham and Barclay 2020, 263-264). To northern border Mexico the collaboration exists and transcends borders. To Duarte, Alexander and O'Brien $(2018,203)$ collaboration in the craft beer sector is basic to increase product quality and "acquire basic knowledge of new recipes and improve strategic knowledge about the industry". In Baja California this is happening, but the behavior of the brewers is associated strongly with a cultural environment. Cultural codes refer to corporate symbolic capital and its 
historical process that is used by the owners and transformed into strategic and dynamic knowledge, according to dynamic capabilities. The argument about sociocultural antecedents in a territory is that it includes values of integrity in businesses that are usually present in an intangible way, included those of the family and family businesses.

Recently the article titled "Knowledge, innovation, and outcomes in craft beer: Theoretical framework and fuzzy-set qualitative comparative analysis" (Cabrera-Flores, Peris-Ortiz and León-Pozo 2020) focused on cultural aspects in the Baja California craft beer. To the author's regional factors as well as wine-growing and gastronomical vocation and the institutional dimension affected favorably the craft beer sector, dynamizing the SMEs knowledge. However, the business culture of a certain place must be understood as a complex dimension interacting with others and not just as a set of causal factors to be foreseeable. For this reason, to analyze the cultural dimension must focus on the so-called symbolic capital from its historical construction which is far away from generalizations. This idea is nearby to the geographical perspective which emphasizing the differentiation and authenticity like Gatrell, Reid and Steiger have shown for the US craft beer sector and its local brandings. The authors explain that "explosion of the craft beer branch [in the US] suggests other dynamics are at work in an industry that is interestingly bimodal with respect to scale and branding: local (craft beer-microbreweries, regional breweries, and brewpubs) and global (macro-breweries)" (Gatrell, Reid and Steiger 2017, 363). But the craft beer industry is itself multimodal and comparison fieldwork in the future needs to assume a new lens directed to local and regional capacities. In Baja California, the multimodal model is expressed in diverse individual and collective dynamics, including the participation of women brewers. 


\subsection{Baja Californian Craft Brewery milieu}

The interest to discuss the craft sector in Mexico characterized by SMEs is due to their existence and impressive rise in the last two decades. It is noteworthy that the existence of craft breweries itself would not make sense if it were not for the aspirations, capabilities, and knowledge of the owners competing for different goals. In Baja California, many microbreweries are located in Tijuana (border city), with more than 120 businesses in 2018. Ensenada and Mexicali cities, the boom has been since 2015. The beer ecosystem in Baja California is full of startups. One of the main characteristics is this place is the permanent link among brewers from California and Baja California. The owners (men and women) are not focused on growing into big companies and thus competing with the big brands. Owners' aspirations are based on quality and related to quality expectation and recognition from consumers and regional beer communities (crews). Geographical and internal business conditions in the craft brewery sector, allow to discuss how the small companies innovate and define their own growth, exploiting their management capabilities improving personal, friendship, fraternal, and parental relations and at the same time taking advantage of the local context of consumption, and collaboration among local and binational brewers crews.

In Baja California those resources are remarkable as entrepreneurial and cultural codes that owners transform inabilities to manage small businesses, as well as introducing constant innovations and collaborative practices. The innovation routes and creativity are visible in the market: different types of beers bottled and draft beer, with special flavors and grains, generating new beers based on Stout, IPA, Porter, Ale, Pilsner, among other styles. Beyond the house elaboration places, the tasting rooms, at least in Baja California, correspond to a new type of social space that offers a diversity of presentation and gastronomic products. From 
Revolución Street in Tijuana to the old building of the Azteca Brewery in Mexicali, and the small places in the port city Ensenada, have become beer temples evoking the urban art, the quality of beer, and local identity in each creation brand. Baja California began the production of beer during the alcohol prohibition in the US, sanctioned by the Volstead Law between 1920 and 1933 (Almaraz 2007). This event in California attracted investments that boosted the local industry accompanied by tourism activities. The most famous brands in those years were ABC (Aztec Brewing Co.), De Anza, Cerveza Mexicali, Cerveza Tijuana, and Cerveza Tecate. Of these, the last three are still functioning. The first brewers were organized by US and Mexican entrepreneurs' groups during the first boom (the 1920s-1930s). Until the 1990s the industrial beer was the only option to satisfy the taste of the population linked to heat weather in the Ensenada area and much more in Mexicali. Now there are three craft beer districts: Tijuana (border city), Ensenada (port City), and Mexicali (border City).

After the prohibition phase in the US, the Baja Californian brewers preserve industries and brands like Cerveza Mexicali, Cerveza Tijuana, and Cerveza Tecate and others succumbed to the arrival of industrial brandings like Cuauhtémoc Moctezuma (from northeast of the country). This large company bought the Tecate Brewery in the 1940s and is still active today recently was merged with Heineken. Ten years ago (2000), in the middle of Baja Californian gastronomy boom, the brewery re-emerged as a craft beer industry evoking the past context. In less than a decade the recognition of different startups has been reflected in important awards achieved. The most recent achievements are observed in the global Rate Beer 2019 ranking. According to Forbes Magazine, Tijuana is heading to be the world capital of craft beer. The Insurgente brewery was awarded as the best Mexican craft beer for its creation Hops and Chill, and Madueño as the best new brewery. Founders-brewers are the creators of many beer brands and 
styles. They are mostly men under 50 years of age, but the role of women dedicated to produce and manage craft breweries is becoming more visible. All of them have created and innovated from one to twenty beers. Some styles are no longer produced, and others have become the brand's trademark. Companies have fewer than 10 employees in all cases. Most of these small companies are formally incorporated into the tax records as individuals with business activity. Only a few brewers remain operating in the informality in the garage.

Sergio Michel and Carlos Maklis are founders of two first craft breweries in Tijuana. Both have different sales strategies, but a common value is their capability to cooperate. The collaboration also is extended to brewers in Mexicali, Ensenada, and California in the US. The beers created by Sergio stand out for the combination of local flavors as chocolate and coffee. Sergio has been inspired by traditional Mexican flavors and his creations have broken styles being careful with the international standards of craft beer (Almaraz 2020), recently opened his tasted room, and bottled some of his creations. Carlos only has a tasting room, and his creations are only on tap.

The owners in Baja California are between 30 and 40 years old, where the participation of women already exceeds $10 \%$ of the businesses, which is distinctive not only in this region but in Mexico. The women brewers have constituted their own association named Mujeres catadoras de cerveza (Women beer tasters) which is led by the brewery Kathy Pedrín from Ensenada. The milieu of SMEs in Baja California also includes informal craft breweries organized in "home garage".

The planning and organization of the businesses in most cases can be followed in private and institutional websites. Many projects have upgraded the factory and home garage to the first 
testing room projects, and some of them have become in restaurants. Another example of the upgrading brewer is the offering of bottled beers and different branding to each style. In the first case the brewers that bottle has upgraded to distribute beers in other regional testing rooms, restaurants, and local supermarkets. In the second, the flexibility to create new styles with your own brand (house brand) and brands for each style is remarkable. Internal diversification is not only the result of creativity and administrative capacities, but of the regional environment itself, and identity performance. It's not as easy for industrial breweries to create new styles and brands too often, or to quickly adapt to consumer preferences, as craft breweries do. Despite the entrepreneurs in Baja California craft beer industry are not impromptu, they are professionals too. Most of them have completed graduate education and have also continued to master beermaking techniques. This feature is very important to manage knowledge and the innovation process. The Baja California brewers also have used the symbolic codes as sub-brands for their styles. Some examples are the branding in allusion to indigenous groups, local animal species, and regional characters. Finally, it is important that in ten years only two companies merged with an industrial group. The breweries were Tijuana and Cucapá that in 2016 made a strategic alliance with Grupo Modelo to market their products.

\subsection{Constant Innovation in Craft Breweries}

In Mexico, the craft beer brands offer flavors and combinations unimaginable in industrial beer. For example, coffee, chocolate, or chili, in addition to essential grains for brewing such as hops, barley malt, and others, preserving general conventions to specific styles. The idea of the isomorphism within the industrial beer sector in Baja California has broken with the increase of women brewers. They are imposing their own styles and breaking business organization schemes being cookers, testers, and judge's beer. Once the first startup phases are completed 
(best idea, financial and organizational planning, first designs), a brewer arrives in the local market, and the sense of competition is focused on the consumers approval to increase productivity. The market entry does not occur in isolation. In Baja California local and regional ties are part of the accompanying codes; the first year in the market collaboration is dense and strategic for the 'new' brewers. Also, the regional crews recognize the best new brewers and adopt them. Sometimes, the limit to growth can be the installed capacity or scarcity of supplies. Then brewers concentrate on quality because is the most important for them; their passion and fascination for experimenting with new combinations of flavors can substitute the quantity produced. The geographical collaboration can help to solve supplies problems.

Unlike other SMEs, the craft brewery depends on innovation and quality to gain prestige. The aspiration of brewers is not aimed at monopoly. Consumers recognize brands and styles. Craft brewers seek creativity and recognition at national and international festivals, but regional consumer taste is the main objective. The crews - themselves named-are not competing with the "industrial beer" brandings; the growth is in another place; the sectorial and firm growth is in different routes to upgrading and collaborating. Competitiveness is represented by the creativity of "brew-masters", "cookers" or "brew chefs" where they are the owners and entrepreneurs. For this reason, in short term, the acceleration and continuity of the craft beer industry depend specifically on them. Visible obstacles for this can be that craft brewers have another business or jobs, crucial events, and/or institutional obstacles, and geographical distance with the suppliers. The craft brewery in Mexico escapes to the isomorphism imposed by the industrial brewery. The dynamic capabilities in Baja California, are pushing variations of Pale Ale, IPA, Amber, Porter, and Stout, and others, with creativity, territorial collaboration 
and cultural codes and passion, all of them compressed in the idea of business symbolic, historical, intangible, and embedded capital.

\section{Final Thoughts}

The craft beer entrepreneurs' examples in this article show that innovation is a process guided by individuals and their creativity, high capacity to collaborate, specialized knowledge, and cultural codes. They do not need high technology issues and their aspirations to become in large firms are not a goal. Furthermore, innovation does not exclude SMEs either. Innovation is a craft beer industry condition that does not depend on the ability to adopt codified and released knowledge. The production of craft beer necessarily requires an understanding of three startup phases. For this reason, some brewers remain in 'house garage (informal). When a planned business is done the brewer access to formal markets. In the Baja Californian milieu exists a multimodal scheme:

\begin{tabular}{|l|l|}
\hline Place of distribution & Type of beer container \\
\hline Home garage & Draft beer \\
\hline Tasting rooms / Tap rooms & Bottled beer, draft beer \\
\hline In alliance with restaurants & Bottled beer, draft beer \\
\hline Stores and supermarkets & Bottled beer \\
\hline
\end{tabular}

Source: based on testimonies.

In Mexico, the fragility of SMEs can be associated with structural conditions, as well as with the internal aspects of the companies, or sectorial aspects. By not having a record per company that allows the knowledge of it general characteristics of business evolution, it is not possible to follow the capabilities and evolution. The heterogeneity of SMEs must therefore be analyzed by milieu (sector, territory, and entrepreneurship). Also, it is relevant to observe three large groups of activities and levels to innovation: a) technological, and software linked industries, which are inherently linked to innovative processes, b) non-technological companies but 
depending and are obliged to innovate in product and/or process, and c) companies that do not depend on innovations in the start-up and that therefore can survive indefinitely without them. Craft beer owners in Baja California understand the importance of innovations and internal control by experts. The entrepreneur's startup considers innovation as an inherent aspect. If this were not considered, there would be a relative disadvantage. The owners, whether men or women, do not acquire their skills by reading a beer book, the activity demands high creativity, continuous improvement, learning, sensitivity, and cultural integration. Penrose's thinking has been inspiring to take a step forward, as well as the authors who later advanced the idea of knowledge, management, and dynamic capabilities.

These brewers in Baja California have experienced different growth and upgrading types. From the "home-garage", to testing rooms the brewers' main aspiration is prestige. The upgrading is associated with products, bottling, and tasting rooms, which mean a combination of creativity, innovation, collaboration, and symbolic business capital. Be merged with industrial brandings is not an option. Only two firms in more than 10 years in Baja California have opted for this way. The food-districts, at Mexicali, Tijuana, and Ensenada (Baja California, 2020a, 2020b, and 2020c) are part of entrepreneurial craft brewery milieu in northern border Mexico, where brewers in most cases belongs to second generation of entrepreneur groups leading local business and not only this type of SMEs.

The "brew master", "cooker" is the key agent in the craft beer milieu. In Baja California they are the entrepreneur and manager, the purchase the equipment, seek new local markets, participate in regional crews, and cook beer. They are learning through their own experimentation and interaction with colleagues, attending courses, and also transferring and getting knowledge through personal and/or collective networks (including family). There are 
two ways to the brewery startup: a) elaboration by experimentation without immediate sale, and b) elaboration by experimentation for immediate sale. In both cases, the investment exceeds $\$$ 500 dollars, and the owners require the basic knowledge to cook beer and financial capacity to buy machinery and supplies. If the entrepreneurs want to venture into the immediate sale, must prepare a name and logo brand (Table 6), and therefore implement a business plan or protocol and do a formal registration, either as an individual or legal entity (anonymous society). This phase does not always happen in other SMEs (services or commerce). The brewing logos creators are usually local artists and professional designers.

The craft brewery in Mexico has positioned itself to such a degree that in principle it is not a sector that requires direct financial support to enter the market. The owners in Northern Mexico in the craft beer milieu usually have a bachelor's degree. The collaboration crosses the border making a Tijuana-San Diego region a context to collaborative work, including owners from Ensenada and Mexicali. It also highlights a combination of annual productive activities as beer festivals in each district and regional stands including California. The current pandemic caused by SARS COV2 contrary to initial expectations had a favorable impact on Baja California craft brewer milieu. The macroeconomic instability did not affect all economic sectors in the same way. The geographical location allowed the breweries to adapt to social mobility restrictions. Brewers organized seminars and conferences named "chevinars" by zoom to offer products and explain to people who they work. At the same time, brewers implemented new distribution networks including their own "taxi-beer", and introduced returnable containers named "growlers", even including hand-labeling. All these strategies allow us to exemplify the dynamic capacities in the Baja California brewery and exhibit the importance of collective actions among brewers. Brewery owners in Baja California changed rapidly to adapt and renew 


\section{Journal of Evolutionary Studies in Business}

their sales competencies from May to December 2020. The dynamic capabilities were amplified the last year. Special design brands and websites alluding to the local and nostalgic culture had in social media the perfect atmosphere to fascinate more people sense. Surely craft beer sector prepares new strategies to prevail in the market and to continue innovating above the current crisis. The specialization as a growth process has not been explored deeper, however, this aspect will be developed in future jobs.

TABLE 6. Baja California Beer brands

(n)

Source: From company websites

Analyzing the craft beer milieu in the Northern border of Mexico invites to reconsider the false limits of business organization and large corporations, demanding new analytical frameworks beyond the size of companies. It is urgent to focus on emerging forms of innovation as collaborative processes in this sector and mature the discussion about the cultural dimension 
associated with the historical process of symbolic business capital. The brewing branch encourages to return to Edith Penrose's argument on difficulties of applying general theories to all companies and her proposition about human motivation and decision (Penrose [1959] 1995, 2). Craft beer owners in Baja California are not reflecting a path to become managers of corporate structures and large companies.

The Baja Californian craft beer milieu (integrated by three local districts, more than 100 companies, male, and female brewers) is linked to social codes that build and preserve a symbolic capital, where owners and consumers are geographically merged by the cultural dimension around craft beer. In this journey, the studies of business history, administration, and other disciplines will have much to contribute. The focus of this work has been SMEs, startups, creativity, innovation, collaboration, and closely the brewer's motivation, as well as the role of the territory and culture in the entrepreneur's aspirations for future comparisons of craft brewery milieus.

\section{References}

Aguilera, Ana María. 2020. "La ambidextría organizacional: El camino a la competitividad." Retrieved August 21, 2020. http://anamariaaguilera.com/ambidextria-organizacional/.

Adner, Ron and Constance E. Helfat. 2003. Corporate effects and dynamic managerial capabilities, Strategic Management Journal (24) pp.1011-1025.

Almaraz, Araceli. 2007. "El boom de las empresas extranjeras en el valle de Mexicali: Efectos en las relaciones empresariales locales (1912-1930)." Frontera norte [online], (19)37 pp.113-142. Retrieved from $\quad$ http://www.scielo.org.mx/scielo.php?script=sci_arttext\&pid=S018773722007000100005\&lng=es\&nrm=iso. .

Almaraz, Araceli. 2020. "Origins of Entrepreneurship: The Other Faces of the Rhombus." In The History of Entrepreneurship in Mexico: contextualizing theory, theorizing context, Araceli Almaraz and Oscar Montiel. 37-66. Bingley: Emerald Publishing. 
Almaraz, Araceli and Oscar Montiel 2020. The History of Entrepreneurship in Mexico: contextualizing theory, theorizing context. Bingley: Emerald Publishing.

Angelelli, Pablo Javier and Juan José Llisterri. 2003. El BID y la promoción de la empresaríalídad: lecciones aprendidas y recomendaciones para nuevos programas, Informe de Trabajo. Washington, DC: BID.

Baja California. 2020a. "Some craft beer recommendations when visiting Ensenada." Retrieved August 21. https://bajacalifornia.travel/some-craft-beer-recommendations-when-visiting-ensenada/

Baja California. 2020b. "The Brewing District of Tijuana." Retrieved August 22. https://bajacalifornia.travel/the-brewing-district-of-tijuana/..

Baja California. 2020c. "Mexicali Cervecerías." Retrieved August 25. https://mexicali.travel/en/breweries/.

Banco Mundial. 2010. Mujeres Empresarias: Barreras y Oportunidades en el Sector Privado Formal. En América Latina y el Caribe. Programa de Promoción de Equidad de Género y Derechos de la Mujer. Washington D.C: Banco Internacional de Reconstrucción y Fomento / Banco Mundial. Bernáldez, Aldo. 2013. "Cerveza artesanal en México: ¿soberanía cervecera y alimentaria?” CULINARIA Revista virtual especializada en Gastronomía 6: 56-63.

Brewers Association. 2020. "Craft Btewer Definition." Retrieved July 22. https://www.brewersassociation.org/.

Cardoni, Andrea, John Dumay, Mateo Palmaccio, and Domenico Celenza. 2018. Knowledge transfer in a start-up craft brewery. Business Process Management Journal, https://doi.org/10.1108/ BPMJ07-2017-0205

Cabrera-Flores, Mayer, Marta Peris-Ortiz, and Alicia León-Pozo. 2020. "Knowledge, innovation, and outcomes in craft beer: Theoretical framework and fuzzy-set qualitative comparative analysis." Journal of Intelligent \& Fuzzy Systems (38): 5369-5378. doi: 10.3233/JIFS-179630.

Cunningham, James and Stephanie Barclay. 2020. "Craft beer sector collaboration in North East Scotland: The role of individual success." The International Journal of Entrepreneurship and Innovation 21(4): 263-274. doi: 10.1177\%2F1465750320921296.

De Maria y Campos, Mauricio. 2002. Pequeñas y medianas empresas industriales y política tecnológica: el caso mexicano de las tres últimas tres décadas. Santiago de Chile: CEPAL.

Deloitte. 2017. "La Cerveza Artesanal. Una experiencia multisensorial." Retrieved July 22. https://www2.deloitte.com/content/dam/Deloitte/mx/Documents/consumerbusiness/2017/Cerveza-Artesanal-Mexico-2017.pdf.

Dini, Marco. 2010. Competitividad, redes de empresas y cooperación empresarial. Santiago de Chile: CEPAL/ILPES/Cooperazione Italiana. 
Domínguez, Lilia and For Brown. 1989. "Nuevas tecnologías en la industria maquiladora de exportación." Comercio Exterior 39(3): 45-68.

Duarte, Alonso, Nevil Alexander, and Seamus O’Brien. 2018. "Collaboration and the Emerging Craft Brewing Industry: An Exploratory Study.” Journal of Asia-Pacific Business 19(3): 203-224. doi: $\underline{10.1080 / 10599231.2018 .1490595 .}$.

Dussel, Enrique. 2004. "Pequeña y mediana empresa en México: condiciones, relevancia en la economía y retos de política." Economía UNAM 1(2): 64-84. Retrieved July 22, 2020. http://www.scielo.org.mx/scielo.php?script=sci_arttext\&pid=S1665952X2004000200006\&lng=es\&nrm=iso.

FIEL. 1996. Las Pequeñas y Medianas Empresas en la Argentina. Buenos Aires: Fundación de Investigaciones Latinoamericanas.

Grand View Research. 2020. "Craft beer market size, share \& trends analysis report by distribution (Ontrade, Off trade), by region (North America, Europe, APAC, Central \& South America, MEA) by country (US, Germany, Australia, Japan) and segment forecasts, 2018-2025. Market Analysis Report.” Retrieved June 2, 2020. https://www.grandviewresearch.com/industry-analysis/craftbeer-market.

Gatrell, Jay, Neil Reid, Thomas L. Steiger, Thomas L. 2017. "Branding spaces: Place, region, sustainability and the American craft beer industry." Applied Geography 90: 360-370. doi: 10.1016/j.apgeog.2017.02.012.

Guillén, Irene, Araceli Rendón, and Andrés Morales. 2016. "Un acercamiento a la competitividad del sector de cerveza artesanal mexicana." Red Internacional de Investigadores en Competitividad Memoria del X Congreso. Last accessed December, 12. https://www.riico.net/index.php/riico/article/view/1326/995.

Heller, Lidia. 2010. Mujeres emprendedoras en América Latina y el Caribe: realidades, obstáculos y desafíos. Santiago de Chile: Naciones Unidas-CEPAL. División de asuntos de género, Serie Mujer y Desarrollo 93.

Hernández, Elena de la Paz. 2015. "Empresarias y ejecutivas en México. Diagnósticos y desafíos." Espiral. Estudios sobre Estado y Sociedad 21(61): 261-267. doi: 10.32870/eees.v21i61.271.

INEGI. 2009. Micro, pequeña, mediana y gran empresa, Censos Económicos. Retrieved July 22, 2020. https://www.inegi.org.mx/contenidos/programas/ce/2009/doc/minimonografias/m pymes.pdf.

INEGI. 2018. ENAPROCE. Retrieved July 22.https://www.inegi.org.mx/programas/enaproce/2018/.

INEGI. 2020. "Comunicado de prensa" 70/20, del 13 de febrero de 2020. Retrieved June 12. https://www.inegi.org.mx/contenidos/saladeprensa/boletines/2020/enoe_ie/enoe_ie2020_02.pdf Núm. 
INEGI. 2021. Colección de estudios sectoriales y regionales. Conociendo la Industria de la Cerveza. Aguascalientes: INEGI.

Inmujeres. 2005. "Las mujeres empresarias en México. Ciudad de México: Instituto Nacional de las mujeres." Retrieved May 14. http://cedoc.inmujeres.gob.mx/documentos_download/100583.pdf.

Lederman, Daniel, Julián Messina, Samuel Pienknagura, and Jamele Rigolini. 2014. El emprendimiento en América Latina. Muchas empresas poca innovación. Washington, DC: Banco Mundial.

Librado, Moisés and Natanael Ramírez. 2020. "Challenges and Perspectives of Entrepreneurship in the Regions of Mexico." In The History of Entrepreneurship in Mexico: contextualizing theory, theorizing context, Araceli Almarazand Oscar Montiel, 83-109. Bingley: Emerald Publishing.

Mexican Beer Association. 2018. "Reporte de la Industria Cervecera Independiente Mexicana." Retrieved March 1. http://acermex.org/wp-content/uploads/2019/11/Reporte-de-la-Industria-.Acermex.pdf.

Molina-Ycaza, Daniel and Angélica Sánchez-Riofrío. 2016. "Obstáculos para la micro, pequeña y mediana empresa en América Latina." Revista Pymes, Innovación y Desarrollo 4(2): 21-36.

OIT. 2015. La Mujer en la gestión empresarial. Cobrando impulso. Ginebra: Organización Internacional del Trabajo. First Edition.

Penrose, Edith. [1959] 1995. The Theory of the growth of the firm. Oxford: Oxford University Press. Third edition.

Recio, Gabriela. 2004. "El nacimiento de la industria cervecera en México, 1880-1910.” Paper presented at the Segundo Congreso Nacional de Historia Económica. Facultad de Economía de la UNAM, Ciudad de México, October 27-29.

SELA. 2016. "Experiencias recientes sobre programas de emprendimiento e incubadoras de empresas en América Latina y el Caribe: Hacia la creación de una economía impulsada por el emprendimiento." Seminario - Taller sobre Emprendimiento "Hacia la creación de una economía impulsada por el emprendimiento - desmitificando el proceso ". Bridgetown, Barbados: SELA.

Teece, David. J., Gary Pisano, and Amy Shuen, Amy. 1997. "Dynamic capabilities and strategic management." Strategic Management Journal 18: 509-533.

Verona, Gianmario, and Davide Ravasi. 2003. "Unbundling dynamic capabilities: an exploratory study of continuous product innovation." Industrial and Corporate Change 12(3): 577-606. doi: https://doi.org/10.1093/icc/12.3.577.

Zollo, Maurizio, and Sidney G. 7 Winter. 2002. Deliberate learning and the evolution of dynamic capabilities. Organization Science 13: 339-351. 


\section{Journal of Evolutionary Studies in Business}

